\title{
Prescriptions of Proton-Pump Inhibitors Non-Compliant with Recommendations
}

\author{
Bosshard $\mathrm{T}^{1^{\star}}$, Perez $\mathrm{J}^{1}$, Pereira $\mathrm{B}^{2}$, Beytout $\mathrm{J}^{1}$, Dubray $\mathrm{C}^{3}$, Sautou $\mathrm{V}^{4}$ and Lesens $\mathrm{O}^{1,5}$ \\ ${ }^{1}$ Service of Infectious and Tropical Diseases, CHU Clermont-Ferrand, Clermont-Ferrand, France \\ ${ }^{2}$ Biostatistics Unit, DRCI, Clermont-Ferrand, France \\ ${ }^{3}$ Center for Clinical Pharmacology, CHU Clermont-Ferrand, Inserm CIC 1405, F-63003, Clermont-Ferrand, France \\ ${ }^{4}$ Gabriel Montpied University Hospital Center, Clermont Ferrand, France \\ ${ }^{5}$ Laboratoire Microorganismes: Génome Environnement (LMGE), Université Clermont Auvergne, Clermont-Ferrand, France
}

"Corresponding author: Thomas Bosshard, Centre Hospialier Universitaire Gabriel Monpied Clermont ferrand, France, Tel: 0033627950220; E-mail: bosshard.th@gmail.com

Received date: October 17, 2016; Accepted date: November 22, 2016; Published date: November 28, 2016

Copyright: ( 2016 Bosshard T, et al. This is an open-access article distributed under the terms of the Creative Commons Attribution License, which permits unrestricted use, distribution, and reproduction in any medium, provided the original author and source are credited.

\begin{abstract}
Context: In 2013, reimbursements for Proton-Pump Inhibitors (PPIs) amounted to nearly 530 million euros in France. PPI usage was subject to official recommendations in France in 2007 and 2009. Six years later, however, they are being prescribed primarily for off-label uses. This study sought to further light the prevalence of noncompliant PPI prescriptions at our institution.
\end{abstract}

Patients and methods: Transversal, descriptive, observational 1-day study including all patients receiving at least one PPI, in all conventional hospitalization and intensive care wards at a university hospital centre. The study excluded day- and week-stay hospitalization wards, the emergency department, as well as the short-term hospitalization and care ward. Besides demographic data, comorbidity was assessed based on the Charlson index. Medications that could potentially interact with PPIs were recorded.

Results: In total, 26 wards participated and 519 patients were assessed, 198 of which (38\%), aged $67 \pm 13$ years on average, were receiving a PPI treatment, were including 113 men (57\%). The average Charlson score was $1.7 \pm$ 2. Amongst these 198 patients, 50 (25\%; IC95\%: [19-32\%]) were taking PPIs in compliance with official recommendations for best clinical practice, and $126(63 \%)$ were additionally undergoing at least one treatment known to cause drug interactions with PPIs. For all included wards, expenditures for PPIs amounted to 31.57 Euros for the study day.

Conclusion: Over one out of three hospitalized patients (38\%) were receiving a PPI ( $23 \%$ had a PPI at arrival). Whilst over half of prescriptions exhibited potential drug interactions, only $25 \%$ of them complied with good clinical practice recommendations. The significant number of such prescriptions may be explained by their low cost, the image of good tolerance they enjoy, a lack of information regarding side-effects and drug interactions, fear of ceasing PPI administration with ensuing peptic ulcers, as well as unwillingness to question a prescription lacking proper scientific basis. Prescribers must, therefore, be better informed.

Keywords: Proton-pump inhibitor; Prescription; Prevalence; Overuse; Side-effect; Iatrogenesis

\section{Introduction}

The category of medications acting upon stomach acidity saw the fourth-highest sales in terms of quantity and fifth-highest in terms of turnover in town in 2013 [1]. Proton-Pump Inhibitor (IPP) prescriptions peaked in 2009 at nearly 970 million euros of annual costs in France [1-2]. Expenditures subsequently underwent a progressive drop to just over 530 million euros in 2013 [3]. That said, although costs to health insurance have dropped sharply, the number of boxes distributed rose from 42 million to 50 million between 2009 and 2013 [3]. Therefore, although PPI costs borne by society are displaying a downward trend, and despite the fact that such medications are often well-tolerated, the rise in volume of PPIs being administered exacerbates exposure to potentially serious side-effects, thereby entailing likely repercussions for public health. Several recent studies have shown a significant link between PPI administration and the occurrence of digestive infections by Clostridium difficile [4-8]. This risk appears to raise with the duration of PPI administration [9] and increased dose levels [10]. Furthermore, PPI administration during treatment of Clostridium difficile may increase the risk of its reoccurrence up to $42 \%$, as the altered gastric $\mathrm{pH}$ may affect gut flora [11]. PPI usage is also associated with increased risk of contracting community- and hospital-acquired pneumonia [12-14]. Other noninfectious diseases are significantly associated with PPI administration: Rise in risk of myocardial infarction and cardiovascular mortality [15]; hyponatremia via potentiation of the hyponatremia-causing effect of other concomitant treatments [16]; bone fractures, particularly of the femoral neck through an increased osteoporosis risk [17,18], and hypo-magnesemia in the event of associated diuretic administration 
[19-21]. Such effects must act as red flags for prescribers, especially in light of additional, potentially serious drug interactions. In particular, these interactions include modifications to serum concentrations of immunosuppressive treatments, antiretroviral drugs (up to threefold rise in raltegravir serum levels) [22,23], clopidogrel (up to $60 \%$ drop in serum levels), [24] as well as effects on the INR balance in patients on vitamin $\mathrm{K}$ antagonists (VKA) [25].

Use of PPIs has been subject to recommendations by the French National Authority for Health (Haute Autorité de Santé [HAS]) since 2009 [26] and the French Agency for the Safety of Health Products (Agence Française de Sécurité Sanitaire des Produits de Santé [AFSSAPS] now called ANSM) [27] since November 2007. They authorities lay out the indications, dosages, and duration of PPI treatment, whilst adhering to marketing authorizations in order to limit PPI prescription to a favorable risk-benefit ratio. Nonetheless, recent studies [28] tend to show that, 6 years later; these drugs are being prescribed primarily for off-label uses.

The objective of this study was to demonstrate the prevalence of non-compliant PPI prescriptions at our university hospital establishment. Secondary study objectives were to assess the main drug interactions, along with additional costs to the university hospital $[29,30]$.

\section{Methods}

\section{Patients and data}

This was a transversal, descriptive, observational, 1-day study including all patients from all conventional hospitalization and resuscitation wards at Gabriel Montpied Hospital (Clermont-Ferrand, Auvergne, France). The study excluded day- and week-stay hospitalization wards, the emergency department, as well the shortterm hospitalization and care ward. The study was carried out on April 28, 2015, without a particular epidemiological context. Data was collected by means of a questionnaire filled out using information retrieved from each patient's paper and digital file. The questionnaires were completed by either a doctor from the ward or by one of the authors.

Each patient's overall condition was assessed based on the Charlson index [31]. This index constitutes a comorbidity score that predicts survival at 10 years. Valid PPI indication was defined based on recommendations by the HAS from 2009 and by the AFSSAPS from November 2007 on using PPIs, with the dosage and duration of prescribed treatment likewise taken into account $[26,27]$. The study was registered at the French National Commission on Informatics and Liberty (Commission Nationale de l'Informatique et des Libertes [CNIL]) under number 0120.

\section{Statistical analysis}

Statistical analyses were performed using Stata software, version 13 (StataCorp, College Station, TX, US). The tests were two-sided, with $\alpha=0.05$. Patient characteristics were described for each group as mean \pm standard-deviation (SD) or median and interquartile range [IQR] for continuous variables, according to statistical distribution (normality assessed using the Shapiro-Wilk test), and as the number of patients (\%) for categorical variables. Comparisons between groups (compliance and non-compliance with prescription recommendations) concerning patient's characteristics were performed using Chi-squared or Fisher exact tests for categorical variables and Student $t$-test or Mann-Whitney test if assumptions of $\mathrm{t}$-test not met ((i) normality and (ii) homoscedasticity studied using the Fisher-Snedecor test) for quantitative parameters.

\section{Results}

In total, 26 wards participated in the study and 519 patients were assessed, 198 of which $(38 \%)$ were receiving a PPI treatment. Patient's age was $67.9 \pm 13.2$ and $57 \%(n=113)$ were men. The average Charlson score was $1.7 \pm 2.0$ (Charlson score $\leq 2: 74 \%$ ). Of the 198 patients included, $50(25 \%$; 95\% CI [19.4-31.9\%]) were taking a PPI in compliance with official good clinical practice recommendations, 94 (47.5\%) of patients were receiving a PPI dosage of $20 \mathrm{mg}$, and 97 (49.0\%) were taking $40 \mathrm{mg}$.

The characteristics of both groups of patients (adherence or nonadherence to PPI prescription recommendations) are provided in Table 1. Higher was the dosage, greater was the tendency for prescriptions to comply with official recommendations. Overall, $60 \%$ (119) of patients receiving PPIs were on treatment for over 2 months. For 20\% (39) of these, an initiation date was found. The median duration of PPI administration was 2.5 years [2-11 years] for prescriptions compliant with recommendations and 3 years [1-10 years] for non-compliant prescriptions $(\mathrm{p}=0.48)$.

\section{Assessment of PPI indications}

The adherence or non-adherence to recommendations depending upon indication is described in Table 2. For ulcer treatment, five prescriptions did not comply with recommendations: One patient was receiving PPI due to suspicion of a gastro duodenal ulcer (GDU) without signs of severity, whilst a fiberoptic endoscopy was to be performed within the next $24 \mathrm{~h}$. Another patient was continuing PPI administration past the treatment end date. A third patient was on PPI for suspected bleeding in the digestive tract, with no fiberoptic endoscopy requested.

The remaining two patients were receiving improper dosages. Regarding the indication for preventing GDUs caused by non-steroidal anti-inflammatory drugs (NSAID) administration, six patients were receiving an insufficient NSAID dosage to justify PPI prescription. In the group initiated on PPIs whilst in intensive care (ICU), four patients were no longer in an ICU, while fifteen others did not meet the criteria justifying PPI treatment. In the epigastralga group, only two treatments had been validated as trial treatments, whereas PPI treatment was never re-assessed for the others. 
Citation: Bosshard T, Perez J, Pereira B, Beytout J, Dubray C, et al. (2016) Prescriptions of Proton-Pump Inhibitors Non-Compliant with Recommendations. J Pharmacovigil 4: 220. doi:10.4172/2329-6887.1000220

\begin{tabular}{|c|c|c|c|c|}
\hline & $\begin{array}{l}\text { Compliance with prescription } \\
\text { recommendations }(n=50)\end{array}$ & $\begin{array}{l}\text { Non-compliance with prescription } \\
\text { recommendations }(n=148)\end{array}$ & Total \% $(n=198)$ & $\mathbf{p}$ \\
\hline Age (years), mean \pm SD & $67.8 \pm 12.4$ & $67.9 \pm 13.5$ & $67.9 \pm 13.2$ & 0.9 \\
\hline Gender male, $\mathrm{n}(\%)$ & $27(54.0)$ & $86(58.1)$ & $113(57.1)$ & 0.6 \\
\hline Charlson score, mean \pm SD & $2.2 \pm 2.3$ & $1.5 \pm 1.9$ & $1.7 \pm 2.0$ & 0 \\
\hline $\begin{array}{l}\text { Prescription in international nonproprietary } \\
\text { names (INN), } \mathrm{n}(\%)\end{array}$ & $11(22.0)$ & $40(27.0)$ & $51(25.8)$ & 0.5 \\
\hline \multicolumn{5}{|l|}{ Doses, n (\%) } \\
\hline $10-20 \mathrm{mg}$ & $18(36.0)$ & $76(51.4)$ & $94(47.5)$ & \multirow{3}{*}{0} \\
\hline $30-40 \mathrm{mg}$ & $28(56.0)$ & $69(46.6)$ & $97(49.0)$ & \\
\hline$>80 \mathrm{mg}$ & $4(8.0)$ & $3(2.0)$ & $7(3.5)$ & \\
\hline \multicolumn{5}{|l|}{ Unit, n (\%) } \\
\hline Intensive care units & $6(12.0)$ & $15(10.1)$ & $21(10.6)$ & \multirow{3}{*}{0.1} \\
\hline Surgical departments & $11(22.0)$ & $60(40.6)$ & $71(35.9)$ & \\
\hline Medical departments & $33(66.0)$ & $73(49.3)$ & $106(53.5)$ & \\
\hline \multicolumn{5}{|l|}{ Administration, $\mathbf{n}(\%)$} \\
\hline Oral route & $46(92.0)$ & $137(92.6)$ & $183(92.4)$ & \multirow{2}{*}{0.9} \\
\hline Voie IV & $4(8.0)$ & $11(7.4)$ & $15(7.6)$ & \\
\hline PPI intake duration (years), median [IQR] & $2.5[2 ; 11]$ & $3[1 ; 10]$ & $3[1 ; 10]$ & 0.5 \\
\hline PPI initiation during hospitalization, $\mathrm{n}(\%)$ & $22(44.9)$ & $58(39.5)$ & $80(40.8)$ & 0.5 \\
\hline
\end{tabular}

Table 1: Patient distribution depending on adherence to PPI prescription recommendations.

\begin{tabular}{|c|c|c|c|c|}
\hline & $\begin{array}{l}\text { All population } \\
\mathrm{n}=198(\%)\end{array}$ & $\begin{array}{l}\text { No conform indication } \\
n=148(\%)\end{array}$ & $\begin{array}{l}\text { Conform Indication } \\
\mathrm{n}=50(\%)\end{array}$ & $\mathbf{p}$ \\
\hline Ulcer treatment & $14(7.1)$ & $5(3.4)$ & $9(18.0)$ & 0.002 \\
\hline $\begin{array}{l}\text { Treatment of NSAID-induced } \\
\text { ulcers }\end{array}$ & $0(0)$ & NA & NA & - \\
\hline $\begin{array}{l}\text { Helicobacter pylori eradication } \\
\text { following gastro-duodenal ulcer }\end{array}$ & $2(1.0)$ & $0(0.0)$ & $2(4.0)$ & 0.06 \\
\hline $\begin{array}{l}\text { Prevention of gastro-duodenal } \\
\text { ulcer recurrences }\end{array}$ & $3(2 \%)$ & $0(0.0)$ & $3(6.0)$ & 0.02 \\
\hline $\begin{array}{l}\text { Prevention of gastro-duodenal } \\
\text { ulcers whilst on NSAIDs }\end{array}$ & $13(6.6)$ & $6(4.1)$ & $7(14.0)$ & 0.02 \\
\hline $\begin{array}{l}\text { Management of esophageal- } \\
\text { reflux }\end{array}$ & $12(6.1)$ & $0(0.0)$ & $12(24.0)$ & $<0.001$ \\
\hline Zollinger-Ellison syndrome & $1(0.5)$ & $0(0.0)$ & $1(2.0)$ & 0.25 \\
\hline PPI initiation in ICU & $25(13)$ & $22(14.9)$ & $3(6.0)$ & 0.1 \\
\hline Corticosteroid-therapy alone & $13(6.6)$ & $12(8.1)$ & $1(2.0)$ & 0.13 \\
\hline Aspirin $(<300 \mathrm{mg}$ ) alone & $7(3.5)$ & $5(6.6)$ & $1(1.6)$ & 0.11 \\
\hline $\begin{array}{l}\text { Clopidrogel/aspirin association } \\
\text { (without NSAIDs }>300 \mathrm{mg} \text { ) }\end{array}$ & $12(6.1)$ & $6(7.9)$ & $6(4.9)$ & 0.39 \\
\hline Epigastralgia & $12(6.1)$ & $10(6.8)$ & $2(4.0)$ & 0.73 \\
\hline No known indication & $75(37.0)$ & $61(41.2)$ & $14(28.0)$ & 0.1 \\
\hline
\end{tabular}

Table 2: Adherence to PPI prescription recommendations depending on PPI indications. 
Citation: Bosshard T, Perez J, Pereira B, Beytout J, Dubray C, et al. (2016) Prescriptions of Proton-Pump Inhibitors Non-Compliant with Recommendations. J Pharmacovigil 4: 220. doi:10.4172/2329-6887.1000220

Page 4 of 6

\section{Description of main associated treatments}

Out of the 198 patients, $126(63 \%)$ were receiving at least one additional treatment (mean of 1.52 , with three patients undergoing a maximum of four associated treatments) known to cause drug interactions with PPIs. Overall, 67 (33\%) patients were receiving low aspirin dosages, but the indications for only 13 out of 67 prescriptions complied with good clinical practice recommendations. The major associated treatments exhibiting notable drug interactions are shown in Table 3.

\begin{tabular}{|c|c|c|c|}
\hline Medications & $\begin{array}{l}\text { Number of patients receiving such } \\
\text { treatment among the } 198 \text { patients on PPI } \\
n(\%)\end{array}$ & $\begin{array}{l}\text { Frequency of validated indication } n \\
(\%)\end{array}$ & Type of interaction \\
\hline \multicolumn{4}{|l|}{ Major interaction } \\
\hline Raltegravir & $1(1)$ & $1(1)$ & $\begin{array}{l}\text { Increase in serum raltegravir levels up to } \\
\text { threefold, [23] }\end{array}$ \\
\hline Clopidogrel & $20(10)$ & $3(2)$ & $\begin{array}{l}\text { Decrease in active metabolite bioavailability up to } \\
50 \text { [24] }\end{array}$ \\
\hline$V_{K A}^{*}$ & $39(20)$ & $6(3)$ & INR modifications [25] \\
\hline Prasugrel & $5(3)$ & $1(1)$ & \\
\hline Tacrolimus & $2(1)$ & 0 & \multirow{7}{*}{$\begin{array}{l}\text { Increase in CYP } 2 \mathrm{C} 19 \text { serum concentrations } \\
\text { within P450 cytochrome }\end{array}$} \\
\hline Methotrexate & $2(1)$ & 0 & \\
\hline Cyclosporine & $3(2)$ & $1(1)$ & \\
\hline Phenytoin & $2(1)$ & 0 & \\
\hline Citalopram & $1(1)$ & 0 & \\
\hline Levetiracetam & $13(7)$ & $4(2)$ & \\
\hline Carbamazepin & $3(2)$ & $1(1)$ & \\
\hline \multicolumn{4}{|l|}{ Minor interactions } \\
\hline Loop diuretics & $58(29)$ & $12(6)$ & \multirow{7}{*}{ Addition of hyponatremic effects [16] } \\
\hline $\mathrm{ACEIs}^{* *}$ & $30(15)$ & $7(4)$ & \\
\hline Thiazid diuretics & $9(5)$ & $2(1)$ & \\
\hline Fluoxetine & $2(1)$ & 0 & \\
\hline Paroxetine & $2(1)$ & 0 & \\
\hline Sodium valporate & $2(1)$ & 0 & \\
\hline Acetazolamid & $3(2)$ & 0 & \\
\hline \multicolumn{4}{|c|}{ *Vitamin $\mathrm{K}$ antagonists } \\
\hline
\end{tabular}

Table 3: Prevalence of drugs exhibiting potential interactions with PPIs.

\section{Economic impact}

In total, on the study day, 99 tablets of INEXIUM $20 \mathrm{mg}, 88$ tablets of INEXIUM $40 \mathrm{mg}$, and 22 pouches of intravenous INEXIUM $40 \mathrm{mg}$ were distributed, resulting in a total of 209 items. Expenditures for INEXIUM amounted to 31.57 Euros for the study day.

\section{Discussion}

Over one out of three patients (38\%) hospitalized in our institution was treated using a PPI. The patients were relatively young (67 years old on average), and displayed low comorbidity rates (74\% exhibited a
Charlson score $\leq 2$ ). Only $25 \%$ of PPI prescriptions complied with good clinical practice recommendations. Over half (63\%) of the prescriptions could potentially cause drug interactions. Overall, $46 \%$ (92/198) of patients were receiving a PPI as part of their normal treatment at arrival at the hospital, 32\% (64/198) of which were noncompliant with good clinical practice recommendations. Whilst the consequences in terms of drug interactions or side effects were potentially significant, additional costs linked to such improper prescriptions seemed marginal (24 euros a day).

The main limit of the study could be due to the lack of information in some patient files. The prevalence of PPI usage resembles that 
observed in studies on hospitalized patients (25-62\% depending on the studies) [32-38]. In international literature, the frequency of improper PPI prescriptions is likewise similar, displaying rates from $12-62 \%$ amongst adults, depending on the studies $[8,32,33,37,39]$. That said, these results should not disguise the methodological differences and heterogeneity of targeted populations.

Both at hospitals and in town, PPIs are generally viewed as innocuous medications. A recent retrospective study that included 2.9 million patients, however, suggests that exposition to PPIs is associated with an increased risk of 1.16 (95\%, 1.09-1.24) of myocardial infarction [15]. Survival analysis in a prospective cohort demonstrated a doubling $(\mathrm{HR}=2 ; 95 \% \mathrm{CI}: 1.07-3.78 ; \mathrm{P}=0.031)$ of cardiovascular mortality [15].

The significant number of such erroneous prescriptions may be accounted for by their low cost, the image of good tolerance they enjoy, a lack of information regarding side-effects and potential drug interactions, fear of developing peptic ulcers on PPI discontinuation, as well as unwillingness to question a prescription lacking proper scientific basis. Reduction in PPI misuse must entail providing better information and awareness-building amongst prescribers. A fact sheet has been drafted to this end (Table 4). Moreover, it would prove beneficial to suggest re-assessment of PPI treatment in the discharge letter to the general practitioner. The general practitioner is, after all, the healthcare actor who is best informed of patients' medical history and in the best position to evaluate whether or not continuing PPI treatment would be appropriate.

\section{1 - Systematic re-assessment of treatment at patient arrival and departure}

2 - No indication in the event of Aspegic $^{\circledR}$ administration (dosage below 300 $\mathrm{mg}$ ), unless high gastrointestinal hemorrhages occur after administering lowdosed NSAIDs

3 - No indication for prescribing PPIs along with antiplatelet drugs, particularly clopidogrel and low-dosed aspirin, or corticosteroids, or anticoagulants (VKA or DOAC), without associated NSAID administration at a dosage exceeding 300 $\mathrm{mg}$ of aspirin equivalent.

4 - No indication in the event of corticosteroid therapy on its own, without associated NSAID administration at a dosage exceeding $300 \mathrm{mg}$ of aspirin equivalent.

Table 4: Prescription optimization in terms of four points corresponding to 65 of on-compliant treatments causes.

\section{References}

1. Assurance Maladie Française (2009) Les prescriptions d'IPP.

2. http://www.securite-sociale.fr/IMG/pdf/ccss200910.pdf

3. http://www.ameli.fr/l-assurance-maladie/statistiques-et-publications/ donnees-statistiques/medicament/medic-am-2008-2013.php

4. Pant C, Madonia P, Minocha A (2009) Does PPI therapy predispose to Clostridium difficile infection? Nat Rev Gastroenterol Hepatol 6: 555-557.

5. Hegarty JP, Sangster W, Harris LR, Stewart DB (2014) Proton pump inhibitors induce changes in colonocyte gene expression that may affect Clostridium difficile infection. Surgery 156: 972-978.

6. Nylund CM, Eide M, Gorman GH (2014) Association of Clostridium difficile infections with acid suppression medications in children. J Pediatr 165: 979-984.

7. Kurti Z, Lovasz BD, Mandel MD, Csima Z, Golovics PA, et al. (2015) Burden of Clostridium difficile infection between 2010 and 2013: Trends and outcomes from an academic center in Eastern Europe. World J Gastroenterol 21: 6728-6735.
8. Marie I, Moutot A, Tharrasse MF, Hellot S, Robaday F, et al. (2007) Adequation aux recommandations des prescriptions des inhibiteurs de la pompe à protons dans un service de médecine interne. La Revue de Médecine Interne 28: 86-93.

9. Barletta JF, El-Ibiary SY, Davis LE, Nguyen B, Raney CR (2013) Proton Pump Inhibitors and the Risk for Hospital-Acquired Clostridium difficile Infection. Mayo Clin Proc 88: 1085-1090.

10. Howell MD, Novack V, Grgurich P, Soulliard D, Novack L, et al. (2010) Iatrogenic gastric acid suppression and the risk of nosocomial Clostridium difficile infection. Arch Intern Med 170: 784-790.

11. Linsky A, Gupta K, Lawler EV, Fonda JR, Hermos JA (2010) Proton pump inhibitors and risk for recurrent Clostridium difficile infection. Arch Intern Med 170: 772-778.

12. Erzig SJ, Doughty C, Lahoti S, Marchina S, Sanan N, et al. (2014) Acidsuppressive medication use in acute stroke and hospital-acquired pneumonia. Ann Neurol 76: 712-718.

13. Eom CS, Jeon CY, Lim JW, Cho EG, Park SM, et al. (2011) Use of acidsuppressive drugs and risk of pneumonia: a systematic review and metaanalysis. CMAJ 183: 310-319.

14. http://ansm.sante.fr/S-informer/Presse-Communiques-Points-presse/ Ventes-de-medicaments-en-France-le-rapport-d-analyse-de-1annee-2013-Communique

15. Shah NH, LePendu P, Bauer-Mehren A, Ghebremariam YT, Iyer SV, et al. (2015) Proton Pump Inhibitor Usage and the Risk of Myocardial Infarction in the General Population. PLoS ONE 10: e0124653.

16. Peyro Saint Paul L, Martin J, Buon M, Gaillard C, Fedrizzi S, et al. (2014) New frequent adverse reaction of PPI in older adults: mild hyponatremia. Therapie 69:157-162.

17. Lewis JR, Barre D, Zhu K, Ivey KL, Lim EM, et al. (2014) Long-term proton pump inhibitor therapy and falls and fractures in elderly women: a prospective cohort study. J Bone Miner Res 29: 2489-2497.

18. Moberg LM, Nilsson PM, Samsioe G, Borgfeldt C (2014) Use of proton pump inhibitors (PPI) and history of earlier fracture are independent risk factors for fracture in postmenopausal women. The WHILA study. Maturitas 78: 310-315.

19. Zipursky J, Macdonald EM, Hollands S, Gomes T, Mamdani MM, et al. (2014) Proton pump inhibitors and hospitalization with hypomagnesemia: a population-based case-control study. PLoS Med 11: e1001736.

20. Atkinson NS, Reynolds DJ, Travis SP (2015) Lemonade Legs: Why do Some Patients Get Profound Hypomagnesaemia on Proton-Pump Inhibitors? Intest Res 13: 227-232.

21. Kieboom BC, Kiefte-de Jong JC, Eijgelsheim M, Franco OH, Kuipers EJ, et al. (2015) Proton Pump Inhibitors and Hypomagnesemia in the General Population: A Population-Based Cohort Study. Am J Kidney Dis 66: 775-782.

22. Placeres Alsina MM, Tuset Creus M, Miró JM (2008) Pharmacokinetics and interactions of raltegravir. Enferm Infecc Microbiol Clin 12: 23-28.

23. Iwamoto M, Wenning LA, Nguyen BY, Teppler H, Moreau AR, et al. (2009) Effects of omeprazole on plasma levels of raltegravir. Clin Infect Dis 48: 489-492.

24. Andersson T, Nagy P, Niazi M, Nylander S, Galbraith H, et al. (2014) Effect of esomeprazole with/without acetylsalicylic acid, omeprazole and lansoprazole on pharmacokinetics and pharmacodynamics of clopidogrel in healthy volunteers. Am J Cardiovasc Drugs 14: 217-227.

25. Hata M, Hayasaka M, Sezai A, Niino T, Yoda M, et al. (2008) Proton pump inhibitors may increase the risk of delayed bleeding complications after open heart surgery if used concomitantly with warfarin. Thorac Cardiovasc Surg 56: 274-277.

26. http://www.has-sante.fr/portail/upload/docs/application/pdf/2009-04/ argumentaire_ipp_2009-04-27_14-15-18_458.pdf

27. http://www.omedithautenormandie.fr/Files/ 107_recommandations_antisecretoire_gastrique_adultes.pdf

28. Ahrens D, Chenot J, Behrens G, Grimmsmann T, Kochen M (2010) Appropriateness of treatment recommendations for PPI in hospital 
Citation: Bosshard T, Perez J, Pereira B, Beytout J, Dubray C, et al. (2016) Prescriptions of Proton-Pump Inhibitors Non-Compliant with Recommendations. J Pharmacovigil 4: 220. doi:10.4172/2329-6887.1000220

Page 6 of 6

discharge letters. Eur J Clin Pharmacol 66: 1265-1271.

29. Hughes JD, Tanpurekul W, Keen NC, Ee HC (2009) Reducing the cost of proton pump inhibitors by adopting best practice. Qual Prim Care 17: 15-21.

30. Cahir C, Fahey T, Tilson L, Teljeur C, Bennett K (2012) Proton pump inhibitors: potential cost reductions by applying prescribing guidelines. BMC Health Serv Res 12: 408

31. Charlson ME, Pompei P, Ales KL, MacKenzie CR (1987) A new method of classifying prognostic comorbidity in longitudinal studies: development and validation. J Chronic Dis 40: 373-383.

32. Sebastian SS, Kernan N, Qasim A, O’Morain CA, Buckley M (2003) Appropriateness of gastric antisecretory therapy in hospital practice. Ir J Med Sci 172: 115-117.

33. Gupta R, Garg P, Kottoor R, Munoz JC, Jamal MM, et al. (2010) Overuse of acid suppression therapy in hospitalized patients. South Med J 103: 207-211.

34. Scagliarini R, Magnani E, Praticò A, Bocchini R, Sambo P, et al. (2005) Inadequate use of acid-suppressive therapy in hospitalized patients and its implications for general practice. Dig Dis Sci 50: 2307-2311.
35. Doherty GA, Cannon MD, Lynch KM, Ayoubi KZ, Harewood GC, et al. (2010) Co-prescription of gastro-protectants in hospitalized patients: an analysis of what we do and what we think we do. J Clin Gastroenterol 44: e51-e56.

36. Pasina L, Nobili A, Tettamanti M, Salerno F, Corrao S, et al. (2011) Prevalence and appropriateness of drug prescriptions for peptic ulcer and gastro-esophageal reflux disease in a cohort of hospitalized elderly. Eur J Intern Med 22: 205-210.

37. Parente F, Cucino C, Gallus S, Bargiggia S, Greco S, et al. (2003) Hospital use of acid-suppressive medications and its fall-out on prescribing in general practice: a 1-month survey. Aliment Pharmacol Ther 17: 1503-1506.

38. Mat Saad AZ, Collins N, Lobo MM, O'Connor HJ (2005) Proton pump inhibitors: a survey of prescribing in an Irish general hospital. Int J Clin Pract. janv 59: 31-34.

39. Ntaios G, Chatzinikolaou A, Kaiafa G, Savopoulos C, Hatzitolios A, et al. (2009) Evaluation of use of proton pump inhibitors in Greece. Eur J Intern Med 20: 171-173. 